\title{
Movement of Oxygen, Glucose, and Lactate across the Uterus of the Awake Near-Term Guinea Pig
}

\author{
LOUIS L. PEETERS, LENA MÅRTENSSON, BERNARD K. VAN KREEL, PRAMOD R. SAXENA, \\ AND HENCK C. S. WALLENBURG \\ Department of Obstetrics and Gynecology and Pharmacology [P.R.S.], Erasmus University Medical School, \\ Rotterdam, The Netherlands
}

\begin{abstract}
In this study the uterine movement of oxygen, glucose, and lactate was quantitated in the awake late pregnant guinea pig. Mean uterine uptake of oxygen per $\mathrm{kg}$ of uterus with conceptus was $581 \mu \mathrm{mol} \mathrm{min}^{-1}$, which is comparable to the value reported for the awake near-term rabbit, but $30 \%$ higher than the value reported for the awake near-term sheep. Experiment-related anemia in some animals was associated with a reduced uterine oxygen uptake. The arteriovenous oxygen difference across the uterus correlated positively with the arterial oxygen content and the hemoglobin concentration and negatively with uteroplacental blood flow. Uterine oxygen uptake showed a positive correlation with both the arterial hemoglobin and the uteroplacental blood flow. Uterine lactate output accounted for $\mathbf{2 0 \%}$ of uterine glucose uptake, assuming maternally derived glucose to be the only source for uterine lactate output. After correction for this lactate output, the uterine glucose uptake was $96.5 \mu \mathrm{mol} \mathrm{min}-1 . \mathrm{kg}^{-1}$ of pregnant uterus. This value is $30 \%$ higher than in the awake near-term rabbit and more than twice as high as that in the awake near-term sheep. Nevertheless, because of the high uterine demand for substrates, this uterine glucose uptake could only cover $45 \%$ of the caloric requirements of the pregnant uterus. The late pregnant guinea pig fetus may derive as much as $\mathbf{5 5 \%}$ of its caloric uptake for fat deposition and protein accretion. Therefore, it is likely that the nonglucose uterine caloric uptake in the late pregnant guinea pig consists predominantly of fat precursors and amino acids. (Pediatr Res 20: 730-734, 1986)
\end{abstract}

Abbreviations

UBF, uteroplacental blood flow

IVC, inferior vena cava

Hb, hemoglobin

UW, uterine weight

The fetuses of the late pregnant guinea pig grow at a rate of $7 \%$ per day and total fetal weight can reach $50 \%$ of maternal prepregnant weight (1). This exceptional characteristic of guinea pig pregnancy implies a great influx of $\mathrm{O}_{2}$ and nutrients into the pregnant uterus during the near-term period and makes this

Received December 9, 1985; accepted March 18, 1986.

Correspondence Dr. Louis L. Peeters, Department of Obstetrics and Gynecology, Erasmus University Medical School EE 2283, P.O. Box 1738, 3000 DR Rotterdam, The Netherlands.

Supported by The Netherlands Organization for the Advancement of Pure Research (ZUYO). species an interesting model for the study of fetal nutrition. However, quantitative data on the movement of $\mathrm{O}_{2}$ and substrates across the uterus of the late pregnant animal can only be derived indirectly from separate studies on the $\operatorname{UBF}(2,3)$ and on mean concentration gradients of various metabolic substrates across the pregnant uterus $(4,5)$. No combined data on UBF and concentration gradients across the uterus obtained in the same animal are available for this species. Therefore, the present study was designed to quantitate the uterine uptake of oxygen and glucose, and the uterine output of lactate in the awake pregnant guinea pig.

\section{MATERIALS AND METHODS}

Nineteen pregnant albino guinea pigs bred in our laboratory facility were used in this study. Dated pregnancies were obtained by using the technique of postpartum breeding (5). The animals were kept in individual cages in a controlled environment $\left(19^{\circ}\right.$ C, $50 \%$ humidity) with a $13 / 11 \mathrm{~h}$ light/dark cycle, from the 30 th day of pregnancy until after completion of the experiments. They were fed commercial guinea pig pellets, ${ }^{1}$ hay, and water ad libitum. Their daily weight gain and food intake was comparable to values reported previously (6). Vitamin $C$ was added to the drinking water twice a week, and vitamin $\mathrm{E}$ once weekly.

Surgical techniques. Between 44 and 50 days gestation, polyethylene catheters were inserted into the left ventricle of the heart, the abdominal aorta and the IVC using aseptic techniques $(3,5)$. The catheters were tunneled subcutaneously and exteriorized between the shoulder blades. They were flushed once weekly with saline. Experiments were performed after complete recovery of the daily weight gain, which was usually on the 4th or 5th day after surgery. The gestational age at the time of the experiment ranged from 50 to 60 days (median 57 days). On the day before the experiment, a small polyvinyl catheter was advanced under fluoroscopic control, through the IVC catheter into one of the ovarian veins $(5,7)$. An arterial blood sample was obtained at this time to determine the $\mathrm{Hb}$ concentration.

Experimental protocol. Three sets of arterial and venous blood samples were collected with an interval of 15 to 30 min between 1000 and $1200 \mathrm{~h}$. The total volume of blood withdrawn was approximately $3.5 \mathrm{ml}$. After blood sampling, UBF was determined using $15 \mu \mathrm{m}$ radioactive microspheres (NEN, Dreieich, West Germany), as described previously (3). Arterial blood pressure and heart rate were monitored continuously throughout the experiment, including the period of blood sampling and microsphere injection. Microspheres were injected only after stable readings for arterial blood pressure and heart rate had been

Composition of Hope Farms guinea pig pellets (LC23-B): carbohydrates (including $13 \%$ fibers): $66 \%$, protein: $23 \%$, fat: $4 \%$, minerals: $6 \%$. Gross energy: 4.5 $\mathrm{kcal} / \mathrm{s}$. 
obtained for at least $15 \mathrm{~min}$. Starting $15 \mathrm{~s}$ before and continuing until $30 \mathrm{~s}$ after the injection, a reference sample of blood was withdrawn at a constant rate $\left(0.9 \mathrm{ml} \cdot \mathrm{min}^{-1}\right)$ from the abdominal aorta. Two separate blood flow measurements were performed about 30 min apart. Some animals moved during one of the two microspheres injections or showed signs of stress reflected in an increase in blood pressure ( $>5$ torr), an increase in heart rate ( $>$ 20 beat per minute), and/or hyperventilation $\left(\mathrm{PCO}_{2}<25\right.$ torr). These measurements were discarded. In the other animals only the measurement with the best correlation between the flows to various organ pairs (indicative of better mixing of microspheres) was used in the subsequent analysis. The difference between the blood flows to paired organs never exceeded $10 \%$.

After the second blood flow measurement, unimpaired venous outflow from the catheterized ovarian vein was verified fluoroscopically using a small bolus of contrast medium (7). After fluoroscopy, the animals were sacrificed with an overdose of pentobarbital sodium. The catheter positions were checked at autopsy, and all organs were dissected. In all animals, the tip of the catheter used for injection of microspheres appeared to be located in a satisfactory position in the left ventricle. The tip of the abdominal catheter was located between the kidneys and the aortic bifurcation. The tip of the ovarian vein catheter was always between 1 and $3 \mathrm{~cm}$ inside one of the ovarian veins.

Radioactivity in each tissue aliquot and in the reference samples was determined with a well scintillation counter adapted with a 3-inch crystal (Packard Autogamma Scintillation Counter 5220). The data were analyzed with a set of computer programs developed for processing data generated during microsphere experiments (8). All uterine, placental, and reference samples contained at least 700 microspheres.

Concentrations of glucose and lactate were determined with standard enzymatic techniques after perchloric acid precipitation (9). The hematocrit was determined in duplicate using the microcapillary technique. The $\mathrm{Hb}$ concentration and $\mathrm{O}_{2}$ saturation were determined with the OSM2-apparatus (Radiometer, Copenhagen, Denmark) and arterial blood gases and $\mathrm{pH}$ with an ABL3 apparatus (Radiometer). The $\mathrm{O}_{2}$ content was calculated from the $\mathrm{Hb}$, the $\mathrm{O}_{2}$ saturation and the $\mathrm{PO}_{2}$ as described previously (5).

Data presentation and statistics. No significant differences could be demonstrated between paired first, second, and third values of $\mathrm{O}_{2}$, glucose, and lactate (paired Student's $t$ test). Therefore, the mean values for the three arterial and venous concentrations were used for statistical evaluation. The uterine uptakes in the present study were calculated based on the data from one uterine horn using the Fick principle. The obtained values were assumed to be representative for the whole uterus. The experimental data of anemic animals were compared with those of nonanemic animals using the unpaired Student's $t$ test. Using Spearman's nonparametric correlation test, the interrelations were evaluated between the three arteriovenous concentration differences and the weight-specific UBF, between the three arterial concentrations and the related arteriovenous concentration differences, and in between the three arteriovenous concentration differences. The relationships between the UBF and the UW and between the arteriovenous $\mathrm{O}_{2}$ difference and the UBF were quantitated with linear regression analysis. Throughout the text data will be presented as means $\pm \mathrm{SD}$.

\section{RESULTS}

Twelve of the 19 animals had an arterial Hb of more than 5.4 $\mathrm{mM}$, which is the lower limit of the normal range (5). Some characteristics and experimental data obtained in the 12 nonanemic and the seven anemic animals are listed in Table 1 . In the anemic as compared with the nonanemic group the arterial lactate concentration was significantly elevated and uterine $\mathrm{O}_{2}$ uptake was significantly reduced. In the nonanemic animals the mean glucose $/ \mathrm{O}_{2}$ and lactate $/ \mathrm{O}_{2}$ quotients across the uterus were $1.23 \pm 0.36$ and $-0.26 \pm 0.08$, respectively. A decreased lactate/ $\mathrm{O}_{2}$ quotient across the uterus most likely reflects increased anaerobic metabolism of the conceptus. Figure 1 illustrates the relationship between this quotient and the weight-specific uterine $\mathrm{O}_{2}$ uptake for nine of 12 nonanemic animals in which both measurements were successfully performed and in all seven

Table 1. Characteristics and experimental data of all pregnant animals studied (mean $\pm S D$ and range)

\begin{tabular}{|c|c|c|c|c|}
\hline \multirow{2}{*}{ Characteristics } & \multicolumn{2}{|c|}{ Nonanemic group $(n=12)$} & \multicolumn{2}{|c|}{ Anemic group $(n=7)^{*}$} \\
\hline & & & & \\
\hline Maternal wt (g) & $1013 \pm 103$ & $884-1193$ & $1048 \pm 182$ & $834-1323$ \\
\hline Fetal wt $(\mathrm{g})$ & $206 \pm 59$ & $81-312$ & $220 \pm 67$ & $129-320$ \\
\hline Litter size & $3.7 \pm 1.3$ & $2-7$ & $3.9 \pm 1.1$ & $3-5$ \\
\hline \multicolumn{5}{|l|}{ Arterial parameters } \\
\hline Hematocrit (vol\%) & $33.5 \pm 3.6$ & $29-40$ & $26.0 \pm 2.5 \dagger$ & $23-29$ \\
\hline $\mathrm{Hb}(\mathrm{mM})$ & $6.5 \pm 0.9$ & $5.4-7.9$ & $4.6 \pm 0.6 \dagger$ & $3.8-5.2$ \\
\hline Glucose (mM) & $4.77 \pm 0.57$ & $3.89-5.83$ & $4.72 \pm 0.82$ & $3.48-6.13$ \\
\hline Lactate $(\mathrm{mM})$ & $1.20 \pm 0.41$ & $0.61-1.84$ & $2.79 \pm 1.98 \$$ & $0.82-6.62$ \\
\hline \multicolumn{5}{|l|}{ Data from sampled horn } \\
\hline Total wt (g) & $143 \pm 60$ & $50-259$ & $169 \pm 45$ & $101-227$ \\
\hline Fetal no. & $2.2 \pm 0.9$ & $1-4$ & $2.6 \pm 0.8$ & $2-4$ \\
\hline Fetal wt $(\mathrm{g})$ & $122 \pm 54$ & $40-233$ & $147 \pm 40$ & $87-199$ \\
\hline Placental wt (g) & $10.6 \pm 4.0$ & $4.5 \pm 16.1$ & $11.2 \pm 4.0$ & $6.8-16.7$ \\
\hline UBF (ml/min/kg.horn) & $143 \pm 37$ & $83-194$ & $124 \pm 35$ & $82-167$ \\
\hline (Arteriovenous) $\mathrm{O}_{2}(\mathrm{mM})$ & $4.18 \pm 0.69$ & $3.06-5.18$ & $3.38 \pm 0.63+$ & $2.72-4.20$ \\
\hline $\begin{array}{l}\text { (Arteriovenous) glucose } \\
\text { (m) }\end{array}$ & $0.94 \pm 0.28$ & $0.43-1.41$ & $0.66 \pm 0.37$ & $0.03-1.26$ \\
\hline$(v-a)$ lactate $(m M) \S$ & $0.39 \pm 0.11$ & $0.29-0.59$ & $1.00 \pm 0.98$ & $0.16-2.64$ \\
\hline Oxygen uptake\| & $581 \pm 114$ & $431-770$ & $410 \pm 116 \dagger$ & $274-635$ \\
\hline Glucose uptake§· $\|$ & $122 \pm 41$ & $58-181$ & $76 \pm 48$ & $5-162$ \\
\hline Lactate output $\S, \|$ & $51 \pm 15$ & $29-80$ & $110 \pm 113$ & $26-340$ \\
\hline
\end{tabular}

* Arterial $\mathrm{Hb}<5.4 \mathrm{mM}$.

$\dagger$ Significant difference between groups I and II $(p<0.01)$.

$\ddagger$ Significant difference between groups I and II $(p<0.05)$.

$\S$ Nine observations.

॥ Expressed in $\mu \mathrm{mol} \cdot \mathrm{min}^{-1} \cdot \mathrm{kg}^{-1}$ of the pregnant uterus. 


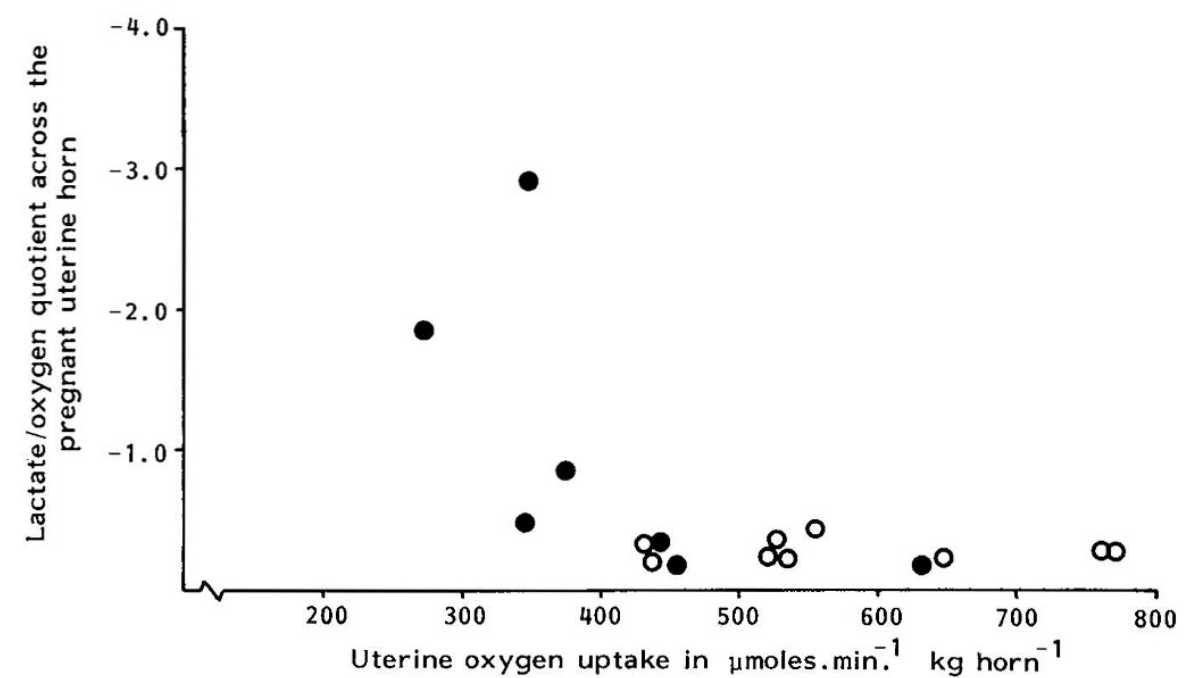

Fig. 1. Relationship between the lactate $/ \mathrm{O}_{2}$ quotient across the uterus and the uterine $\mathrm{O}_{2}$ uptake. Nonanemic animals are represented by open circles, whereas the seven anemic animals are represented by filled circles. Note the decreased quotient when the uterine $\mathrm{O}_{2}$ uptake is less than 350 $400 \mu \mathrm{mol} / \mathrm{min} / \mathrm{kg}$ (uterus + conceptus).

anemic animals. Less than approximately $400 \mu \mathrm{mol}$ of $\mathrm{O}_{2}$ uptake, the lactate $/ \mathrm{O}_{2}$ quotient appeared to fall progressively. Only the data obtained in the 12 nonanemic animals were used for the subsequent statistical analysis. The arteriovenous concentration differences of $\mathrm{O}_{2}$, glucose, and lactate did not correlate with the total weight of the uterine horn. On the other hand, the UBF varied as a function of $\mathrm{UW}(\mathrm{UBF}=0.12 \mathrm{UW}+2.82, r=0.84$, $p<0.001$ ). Therefore, the movement of $\mathrm{O}_{2}$, glucose, and lactate across the uterus varied in proportion to the UBF. The total weight of the sampled uterine horn did not correlate with gestational age due to the variation in the number of fetuses.

Evaluation of the relationships between the three arteriovenous concentration gradients and the UBF showed only a significant negative correlation between the arteriovenous $\mathrm{O}_{2}$ difference and the UBF (Spearman $r=-0.68 ; p<0.01$ ). This relationship was quantitated with linear regression (Fig. 2). The arteriovenous $\mathrm{O}_{2}$ difference correlated positively with the arterial $\mathrm{O}_{2}$ content (Spearman $r=0.51, p<0.05$ ) and with the arterial Hb (Spearman $r=0.48, p<0.05)$. The arteriovenous glucose and lactate differences across the uterus did not correlate with their arterial concentration. Finally, the three arteriovenous concentration gradients were not interrelated.

\section{DISCUSSION}

An important finding in this study is the significantly lower uterine $\mathrm{O}_{2}$ uptake in the anemic as compared with the nonanemic guinea pig without demonstrable interference with pregnancy. The reduced uterine $\mathrm{O}_{2}$ uptake in anemia is caused by the lower arteriovenous $\mathrm{O}_{2}$ difference across the uterus without a significant change in UBF. It is possible that the UBF in a state of anemia can not be increased because of the limited cardiovascular reserves in the late pregnant guinea pig (3). In four of the seven anemic animals uterine $\mathrm{O}_{2}$ uptake was less than $400 \mu \mathrm{mol}$. $\min \cdot^{-1} \cdot \mathrm{kg}^{-1}$ of pregnant uterus (Fig. 1). In these animals, the concomitant lactate $/ \mathrm{O}_{2}$ quotient across the uterus was significantly lower than the mean value for nonanemic animals (Table 1). These data suggest that the lower limit of the normal range of uterine $\mathrm{O}_{2}$ uptake is approximately $400 \mu \mathrm{mol}^{-1} \cdot \mathrm{min}^{-1} \cdot \mathrm{kg}^{-1}$ of pregnant uterus.

Values for UBF, arterial $\mathrm{O}_{2}$, glucose, and lactate concentrations, the related arteriovenous concentration gradients and the glucose $/ \mathrm{O}_{2}$ quotient across the uterus in the 12 nonanemic animals are comparable with previous observations in our laboratory $(3,5)$. The relationship between UBF and UW found in this study is almost identical to that reported previously (3). The

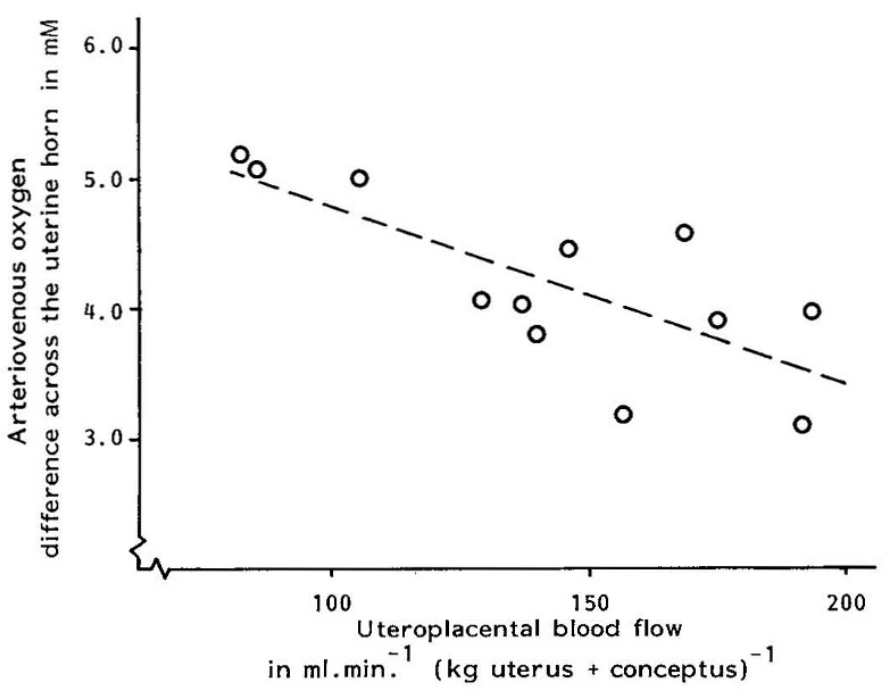

Fig. 2. Relationship between the arteriovenous $\mathrm{O}_{2}$ difference across the uterus and the weight-specific UBF. Linear regression analysis resulted in the equation: arteriovenous $\mathrm{O}_{2}=6.20-0.014 \mathrm{UBF}(r=-0.76$, $p<0.005$ ).

uterine $\mathrm{O}_{2}$ uptake in the present study ranges from 431 to 770 $\mu \mathrm{mol} \cdot \mathrm{min}^{-1} \cdot \mathrm{kg}^{-1}$ of the pregnant uterus (Table 1 ). This relatively large variation may be largely attributed to the methods used: the measurement of UBF as well as that of the arteriovenous $\mathrm{O}_{2}$ difference is associated with a coefficient of variation of $10-15 \%$ $(3,5)$. Multiplication of these two variables to calculate uptake magnifies these errors to $20-30 \%$. The mean value for uterine $\mathrm{O}_{2}$ uptake in this study is $581 \mu \mathrm{mol} \cdot \mathrm{min}^{-1} \cdot \mathrm{kg}^{-1}$ (uterus + conceptus). This value is higher than the approximately 400 $\mu \mathrm{mol} \cdot \mathrm{min}^{-1} \cdot \mathrm{kg}^{-1}$ reported previously for the near-term guinea pig (10). However, the latter observations were made only $2 \mathrm{~h}$ after surgery and anesthesia, when uteroplacental and fetal metabolism may still be suppressed $(11,12)$.

The negative relationship between the arteriovenous $\mathrm{O}_{2}$ difference and UBF decreases the dependence of the uterine $\mathrm{O}_{2}$ uptake of the two contributing variables. In the present study UBF varied between approximately 80 and $200 \mathrm{ml} \cdot \mathrm{min}^{-1} \cdot \mathrm{kg}^{-1}$ (uterus + conceptus) (Table 1). Despite the observed negative correlation between UBF and arteriovenous $\mathrm{O}_{2}$ difference across the uterus (Fig. 2), uterine $\mathrm{O}_{2}$ uptake varies in proportion to both UBF and arteriovenous $\mathrm{O}_{2}$ difference. The insufficient compensatory in- 
crease in the arteriovenous $\mathrm{O}_{2}$ gradient across the uterus in response to a fall in UBF may well be a consequence of the relatively high uterine $\mathrm{O}_{2}$ extraction of approximately $65 \%$ in this species in the late pregnancy (5). At normal UBF rates, the uterus of the late pregnant guinea pig extracts three times as much $\mathrm{O}_{2}$ than does the ewe of corresponding gestational age (13). This so-called "efficiency of uterine $\mathrm{O}_{2}$ uptake" (14) may explain why the guinea pig is able to accomodate such a large conceptus. The mean uterine $\mathrm{O}_{2}$ uptake in this study is about $50 \%$ higher than strictly needed for uterine oxidative requirements. The "excess" $\mathrm{O}_{2}$ uptake may be used by the fetus for nonvital purposes such as bodily movements and tissue growth. In the presence of a compromised UBF, both functions can be curtailed to protect basal energy metabolism.

The values of uterine $\mathrm{O}_{2}$ uptake obtained in the present study are similar to those reported for the awake near-term rabbit (approximately $530 \mu \mathrm{mol} \cdot \mathrm{min}^{-1} \cdot \mathrm{kg}^{-1}$ ) (15) and about $30 \%$ higher than those observed in the awake late pregnant sheep (12) and cow (16). The fractional distribution of the uterine $\mathrm{O}_{2}$ uptake between uteroplacental and fetal tissue can only be determined when the $\mathrm{O}_{2}$ uptake of one of these two tissues is known. Values reported from in vitro measurements of placental $\mathrm{O}_{2}$ uptake in the sheep, rabbit, rat, mouse, guinea pig, and man range from $100-500 \mu \mathrm{mol} \cdot \mathrm{min}^{-1} \cdot \mathrm{kg}^{-1}(17-20)$. However, an in vivo study in the near-term ewe demonstrated the importance of intact uteroplacental and umbilical circulations as well as the absence of anesthesia for normal uteroplacental $\mathrm{O}_{2}$ consumption (12). In the latter study the uteroplacental $\mathrm{O}_{2}$ uptake, measured in the awake near-term ewe with intact uterine and umbilical circulations, amounted to $980 \mu \mathrm{mol} \cdot \mathrm{min}^{-1} \cdot \mathrm{kg}^{-1}$. If the in vivo weightspecific uteroplacental $\mathrm{O}_{2}$ uptake in the near-term guinea pig is assumed to be as high as in the near-term ewe, the fetal $\mathrm{O}_{2}$ uptake can be estimated from the value for the uterine $\mathrm{O}_{2}$ uptake. In the present study, uterine weight consisted for $85 \%$ of fetal mass and for $15 \%$ of uteroplacental tissue (Table 1). A mean uterine $\mathrm{O}_{2}$ uptake of $581 \mu \mathrm{mol}$ is then associated with a fetal $\mathrm{O}_{2}$ uptake of approximately $511 \mu \mathrm{mol} \cdot \mathrm{min}^{-1} \cdot \mathrm{kg}^{-1}$. An over- or underestimation of the weight-specific uteroplacental $\mathrm{O}_{2}$ uptake by $20 \%$ would change the fetal value by only $7 \%$. Therefore, this estimate may be accepted to be a close approximation of the actual fetal $\mathrm{O}_{2}$ uptake. It is striking that it is $42 \%$ higher than the value of $360 \mu \mathrm{mol} \cdot \mathrm{min}^{-1} \cdot \mathrm{kg}^{-1}$ reported for the near-term sheep (21). However, the near-term fetal guinea pig contains $76 \%$ water, less than the $83.3 \%$ of the fetal lamb of corresponding gestational age $(1,22)$. On the basis of these data a fetal $\mathrm{O}_{2}$ uptake (expressed per $\mathrm{kg}$ of dry weight) of $2.1 \mu \mathrm{mol} / \mathrm{min}$ can be calculated for both species.

The reported value of total $\mathrm{O}_{2}$ uptake of $600 \mu \mathrm{mol} \cdot \mathrm{min}^{-1}$. $\mathrm{kg}^{-1}(23)$ in the adult guinea pig appears to be slightly higher than that estimated for fetal $\mathrm{O}_{2}$ uptake. In contrast, fetal $\mathrm{O}_{2}$ consumption per $\mathrm{kg}$ is clearly higher than that of the mother (24) in many larger animals. For instance, the late pregnant fetal lamb consumes twice as much $\mathrm{O}_{2}$ per $\mathrm{kg}$ than the mother (360 versus $\left.180 \mu \mathrm{mol} \cdot \mathrm{min}^{-1} \cdot \mathrm{kg}^{-1}\right)$. It has been postulated that the low $\mathrm{O}_{2}$ requirements of the fetus per unit of body weight as compared to that of the mother enables the guinea pig to grow a conceptus that is relatively larger than that in the sheep for example (24).

In this study no relationship is observed between the arterial glucose concentration and the arteriovenous glucose gradient across the uterus. This observation is in contrast with previous observations obtained in comparable experimental conditions in various other species (25). A correlation between the arterial glucose concentration and the arteriovenous glucose difference may remain undetected because of the relatively small range of arterial glucose concentrations in this study (Table 1). The mean uterine glucose uptake in this study is $122 \mu \mathrm{mol} \cdot \mathrm{min}^{-1} \cdot \mathrm{kg}^{-1}$. The uterine lactate output accounts for $20 \%$ of uterine glucose uptake, assuming no uterine lactate production from other sources. The "net" uterine glucose uptake, which is defined as the uterine glucose uptake after subtraction of the lactate output, amounts to $96.5 \mu \mathrm{mol} \cdot \mathrm{min}^{-1} \cdot \mathrm{kg}^{-1}$ of pregnant uterus. In the near-term sheep (11) and rabbit (15) values for net uterine glucose uptake have been found to be 40 and $70 \mu \mathrm{mol} \cdot \mathrm{min}^{-1} \cdot \mathrm{kg}^{-1}$ of pregnant uterus, respectively.

The caloric value of the guinea pig fetus has been determined at various points in gestation in a cross-sectional study using bomb calorimetry (1). Using the equations reported in that study the values for the daily fetal accretion of water, fat, protein, and non-fat and non-protein substances (glycogen, minerals, etc.) have been calculated for the 57 days pregnant guinea pig. In addition, the caloric equivalent of the fetal $\mathrm{O}_{2}$ consumption was calculated using the estimated value derived from the data on uterine $\mathrm{O}_{2}$ uptake in the present study. The results of these calculations are listed in Table 2 . The net uterine glucose uptake in this study was $96.5 \mu \mathrm{mol} \cdot \mathrm{min}^{-1} \cdot \mathrm{kg}^{-1}$ of pregnant uterus. The caloric equivalent of glucose equals $0.74 \mathrm{kcal} \cdot \mathrm{mmol}^{-1}$. Consequently, the caloric equivalent of the net glucose uptake can be calculated to be $0.0965 \times 0.74 \times 1440(\min )=102.8 \mathrm{kcal}$. day $^{-1} \cdot \mathrm{kg}^{-1}$ of pregnant uterus. This value represents $45 \%$ of the total fetal caloric requirements. Since the weight-specific uteroplacental glucose consumption is relatively large (12), it is likely that the uterine glucose uptake will cover less than $40 \%$ of the fetal caloric requirements. About $55 \%$ of the fetal caloric requirements are needed to generate new protein and fat (Table 2). The high caloric accretion in protein and fat may be accepted to have an important impact on fetal $\mathrm{O}_{2}$ uptake. The energy costs for synthesis may range from $10 \%$ (fat) to $30 \%$ (protein) of the accreted caloric value (26), which corresponds with almost $30 \%$ of the fetal $\mathrm{O}_{2}$ uptake. The high accretion rate in protein and fat is also likely to be associated with a large fractional uptake of amino acids and fat precursors by the pregnant uterus. The guinea pig placenta is readily permeable for free fatty acids (27). In addition, fat precursors of maternal origin contribute importantly to the lipids in the fetal tissues (28). Quantitation of the uterine uptake of fat precursors using the Fick principle may be difficult. The relatively large molecular weight of the most important fat precursors, the free fatty acids, will couple a small gradient across the uterus in $\mu \mathrm{M}(5)$ with a high transplacental transfer rate in grams. Also the amino acids are known to be

Table 2. Fetal metabolism and growth in 57 days pregnant guinea pig*

\begin{tabular}{lcccc}
\hline & $\begin{array}{c}\mathrm{O}_{2} \text { uptake } \\
(\mathrm{mmol})\end{array}$ & $\begin{array}{c}\text { Tissue accretion } \\
(\mathrm{g})\end{array}$ & $\begin{array}{c}\text { Caloric equivalent } \\
(\mathrm{kcal})\end{array}$ & $\begin{array}{c}\text { Fraction of } \\
\text { total caloric uptake } \\
(\%)\end{array}$ \\
\hline Water & & 41.7 & 0 & 0 \\
Fat & 7.3 & 67.9 & 29.8 \\
Protein & 10.2 & 56.1 & 24.6 \\
Other tissue & & 6.8 & 21.7 & 9.5 \\
Total growth & & 66.0 & 145.7 & 63.9 \\
O $_{2} \dagger$ & & 80.7 & 35.6 \\
\hline
\end{tabular}

* The growth of each type of fetal tissue is calculated on the basis of data reported by Sparks et al. (1). Values are expressed per kg of fetal weight and per day.

$\dagger$ Caloric equivalent of oxygen equals $109.7 \mathrm{kcal} / \mathrm{mole}$ of $\mathrm{O}_{2}$ (STP) (25). 
easily transferred across the guinea pig placenta by an active carrier system (29). The question remains to be answered whether glucose serves primarily as a fuel for the oxidative metabolism, and fat precursors and amino acids as building stones for fetal growth. The metabolic fate of each nutrient within the uteroplacental compartment can only be determined in studies which involve the continuous infusion of labeled nutrients into the maternal circulation.

\section{REFERENCES}

1. Sparks JW, Girard J, Callikan S, Battaglia FC 1985 Growth of the fetal guinea pig: physical and chemical characteristics. Am J Physiol 248:E132-E139

2. Myers SA, Sparks JW, Makowski EL, Meschia G, Battaglia FC 1982 Relationship between placental blood flow and placental and fetal size in guinea pig. Am J Physiol 243:H404-H409

3. Peeters LLH, Grutters G, Martin CB 1980 The distribution of cardiac output in the unstressed pregnant guinea-pig. Am J Obstet Gynecol 138:1177-1184

4. Block SM, Sparks JW, Johnson RL, Battaglia FC 1985 Metabolic quotients of the gravid uterus of the chronically catheterized guinea pig. Pediatr Res 19:840-845

5. Peeters LLH, Mårtensson L, van Kreel BK, Wallenburg HCS 1984 Uterine arterial and venous concentrations of glucose, lactate, ketones, free fatty acids, and oxygen in the awake pregnant guinea pig. Pediatr Res 18:11721175

6. Sparks JW, Pegorier JP, Girard J, Battaglia FC 1981 Substrate concentration changes during pregnancy in the guinea pig studied under unstressed steady state condition. Pediatr Res 15:1340-1344

7. Peeters LLH, Mårtensson L, Gilbert M, Pénicaud L 1984 The pregnant guinea pig, rabbit and rat as unstressed catheterized models. In: Animal Models in Fetal Medicine, vol IV. Nathanielsz PW (ed) Perinatology Press Inc, Ithaca, NY, pp 77-108

8. Saxena PR, Schamhardt HC, Forsyth RP, Loeve J 1980 Computer programs for the radioactive microsphere technique. Determination of regional blood flows and other hemodynamic variables in different experimental conditions. Comp Prog Biomed 12:63-84

9. Bergmeyer HU (ed) 1974 Methods of Enzymatic Analysis, Vols 2-4. Academic Press Inc, New York

10. Moll W, Kunzel W, HG Ross 1970 Gas exchange of the pregnant uterus of anaesthetized and unanaesthetized guinea pigs. Respir Physiol 8:303-310

11. Battaglia FC, Meschia G 1981 Foetal and placental metabolism: their interrelationship and impact upon maternal metabolism. Proc Nutr Soc 40:99-113

12. Meschia G, Battaglia FC, Hay WH, Sparks JW 1980 Utilization of substrates by the ovine placenta. Fed Proc 39:245-249
13. Murray RD, Jones RO, Johnson R, Meschia G, Battaglia FC 1985 Uterine and whole body oxygen extractions in the pregnant rabbit under chronic steady-state conditions. Am J Obstet Gynecol 152:709-715

14. Bartels H 1970. In search of the "best" placenta. In: Bartels H (ed) Prenatal Respiration. North Holland, Amsterdam, pp 121-123

15. Johnson RL, Block SM, Gilbert M, Battaglia FC, Maschia G 1983 Uterine oxygen and substrate uptakes of the pregnant rabbit under chronic steady state conditions. Proc Soc Gynecol Invest 113:(abstr)

16. Comline RS, Silver M 1976 Some aspects of fetal and uteropiacental metabolism in cows with indwelling umbilical and uterine vascular catheters. $J$ Physiol (Lond) 260:571-586

17. Campbell AGM, Dawes GS, Fishman AP, Hyman AI, James GB 1966 The oxygen consumption of the placenta and fetal membranes in the sheep. J Physiol 182:439-464

18. Carstensen MH, Leichtweiss HP, Schroeder H 1982 The metabolism of the isolated artifically perfused guinea pig placenta. I. Excretion of hydrogen ions, ammonia, carbon dioxide and lactate, and the consumption of oxygen and glucose. J Perinat Med 147:147-153

19. Raye JR, Killam AP, Battaglia FC, Makowski EL, Meschia G 1971 Uterine blood flow and $\mathrm{O}_{2}$ consumption following fetal death in sheep. Am J Obstet Gynecol 111:917-924

20. Illsey NP, Penfold P, Bardsley SE, Tracey BM, Aarnoudse JG 1983 The effects of anoxia on human placental metabolism and fetal substrate profiles investigated by an in vitro placental perfusion technique. Trophoblast Res 1:5570

21. Bell AW, Battaglia FC, Makowski EL, Meschia G 1985 Relationship between metabolic rate and body size in fetal life. Biol Neonate 47:120-123

22. Rattray PV, Garrett WN, East NE, Hinman N 1974 Growth, developmen and composition of the ovine conceptus and mammary gland during pregnancy. J Animal Sci 38:613-626

23. Morton M, Tsang H, Hohimer R, Ross D, Thornburg K, Faber J, Metcalfe J 1984 Left ventricular size, output, and structure during guinea pig pregnancy. Am J Physiol 246:R40-R48

24. Battaglia FC, Meschia G 1978 Principal substrates of fetal metabolism. Physiol Rev 58:499-527

25. Simmons MA, Battaglia FC, Meschia G 1979 Placental transfer of glucose. J Dev Physiol 1:227-243

26. van Es AJH 1980 Energy costs of protein deposition. In: Buttery PJ, Lindsay DB (eds) Protein Deposition in Animals. Butterworths, London, pp 215 224

27. Jones CT 1976 Lipid metabolism and mobilisation in the guinea pig during pregnancy. Biochem J 156:357-365

28. Thomas CR, Lowy C 1984 Contribution of circulating maternal lipids to feta tissues in the guinea pig. J Dev Physiol 6:143-151

29. v Dijk JP, v Kreel BK 1978 Transport and accumulation of alpha-aminoisobutyric acid (A.I.B.) in the guinea pig placenta. Pfluegers Arch 377:217-224 